\title{
"Addressing Unemployment challenge through micro and small enterprises (MSEs): Evidence from Nigeria"
}

\begin{tabular}{|c|c|}
\hline \multirow{7}{*}{ AUTHORS } & Oluwatoyin Matthew iD https://orcid.org/0000-0003-3876-3479 \\
\hline & R http://www.researcherid.com/rid/M-8721-2013 \\
\hline & Daniel E. Ufua \\
\hline & Romanus Osabohien iD https://orcid.org/0000-0003-4359-1368 \\
\hline & R http://www.researcherid.com/rid/R-2284-2019 \\
\hline & Tomike Olawande \\
\hline & Oluwatosin D. Edafe \\
\hline ARTICLE INFO & $\begin{array}{l}\text { Oluwatoyin Matthew, Daniel E. Ufua, Romanus Osabohien, Tomike Olawande } \\
\text { and Oluwatosin D. Edafe (2020). Addressing Unemployment challenge through } \\
\text { micro and small enterprises (MSEs): Evidence from Nigeria. Problems and } \\
\text { Perspectives in Management, 18(2), 79-89. doi:10.21511/ppm.18(2).2020.08 }\end{array}$ \\
\hline DOI & http://dx.doi.org/10.21511/ppm.18(2).2020.08 \\
\hline RELEASED ON & Monday, 04 May 2020 \\
\hline RECEIVED ON & Monday, 04 March 2019 \\
\hline \multirow[t]{2}{*}{ ACCEPTED ON } & Monday, 10 February 2020 \\
\hline & $((c))$ EY \\
\hline LICENSE & $\begin{array}{l}\text { This work is licensed under a Creative Commons Attribution } 4.0 \text { International } \\
\text { License }\end{array}$ \\
\hline JOURNAL & "Problems and Perspectives in Management" \\
\hline ISSN PRINT & $1727-7051$ \\
\hline ISSN ONLINE & $1810-5467$ \\
\hline PUBLISHER & LLC "Consulting Publishing Company "Business Perspectives" \\
\hline FOUNDER & LLC "Consulting Publishing Company "Business Perspectives" \\
\hline
\end{tabular}

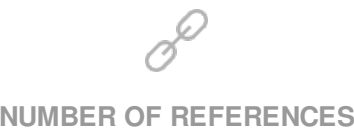

38
NUMBER OF FIGURES

0
NUMBER OF TABLES

4

(C) The author(s) 2022. This publication is an open access article. 


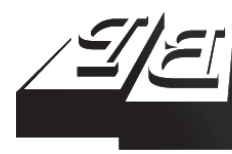

BUSINESS PERSPECTIVES

()

LLC "CPC "Business Perspectives" Hryhorii Skovoroda lane, 10, Sumy, 40022, Ukraine www.businessperspectives.org

Received on: $4^{\text {th }}$ of March, 2019 Accepted on: $10^{\text {th }}$ of February, 2020 Published on: $4^{\text {th }}$ of May, 2020

(c) Oluwatoyin A. Matthew, Daniel E. Ufua, Romanus Osabohien, Tomike Olawande, Oluwatosin D. Edafe, 2020

Oluwatoyin A. Matthew, Ph.D., Senior Lecturer, Department of Economics and Development Studies, Covenant University, Ota, Nigeria; Fellow, Centre for Economic Policy and Development Research- CEPDeR, Covenant University, Ota, Nigeria.

Daniel E. Ufua, Ph.D., Lecturer, Department of Business Management, Covenant University, Ota, Nigeria; Fellow, Centre for Economic Policy and Development Research- CEPDeR, Covenant University, Ota, Nigeria.

Romanus Osabohien, Ph.D. Student, Lecturer, Department of Economics and Development Studies, Covenant University, Ota, Nigeria; Fellow, Centre for Economic Policy and Development Research- CEPDeR, Covenant University, Ota, Nigeria. (Corresponding author)

Tomike Olawande, Ph.D., Lecturer, Department of Sociology, Covenant University, Ota, Nigeria.

Oluwatosin D. Edafe, Graduate Student, Department of Economics and Development Studies, Covenant University, Ota, Nigeria; Fellow, Centre for Economic Policy and Development Research- CEPDeR, Fellow, Centre for Economic Policy and Development Research- CEPDeR, Covenant University, Ota, Nigeria.

This is an Open Access article, distributed under the terms of the Creative Commons Attribution 4.0 International license, which permits unrestricted re-use, distribution, and reproduction in any medium, provided the original work is properly cited.

Conflict of interest statement: Author(s) reported no conflict of interest
Oluwatoyin A. Matthew (Nigeria), Daniel E. Ufua (Nigeria), Romanus Osabohien (Nigeria), Tomike Olawande (Nigeria), Oluwatosin D. Edafe (Nigeria)

\section{ADDRESSING UNEMPLOYMENT CHALLENGE THROUGH MICRO AND SMALL ENTERPRISES (MSES): EVIDENCE FROM NIGERIA}

\begin{abstract}
This study examined the operational characteristics of MSEs and their contributions towards addressing the national challenge of unemployment. The research was based on Ado-Odo/Ota Local Government Area in Ogun State, Nigeria. The study employed descriptive analysis and Ordinary Least Square (OLS) regression technique in estimating the data obtained. The administration of questionnaire was applied to collect the data. The study found out that micro and small-scale enterprises contributed to economic growth through their operational activities, via the job creation in the economy. Thus, the study recommended that government policies should be put in place to encourage micro and small enterprises, and the provision of infrastructures, credit facilities, tax holidays, training program, amongst others, for MSEs. It was also recommended for funding agencies to consider the trends of practicing MSEs towards addressing critical economic and social issues such as job creation, in granting them funding facilities, in order to facilitate continuous participation in job creation among Nigerian MSEs.
\end{abstract}

\section{Keywords}

developing economy, job creation, MSEs' operations, MSEs' partnership, MSEs' operational challenges

\section{JEL Classification $\quad$ O12, M51}

\section{INTRODUCTION}

Nowadays, micro and small-scale enterprises create the platform for economic growth through their significant contribution to job creation over the world. Small and medium-sized enterprises have been recognized as the basis for rapid economic growth and development in the developing countries, including Nigeria, through their potential for job creation and output production. In fact, micro and small enterprises are now seen as a way of creating jobs and growth in advanced economies' restructuring (Stokes, 2000; Matthew, Ede, Osabohien, Ejemeyovwi, Fasina, \& Akinpelumi, 2018a). Extant literature shows that access to credit impact on productivity (Osabohien, Osuagwu, Osabuohien, Ekhator-Mobayode, Matthew, \& Gershon, 2020). This is essential for micro and small enterprises which are considered to be a fundamental component in creating a modern, progressive, and vibrant economy (Stokes, 2000; Matthew et al.,2018a). therefore, good institutions and policies are necessary requirements for business to strife in an economy (Igharo et al., 2020; Beecfroft et al. 2020). For instance, Shibia and Barako (2017) reckon that the effects of MSEs in Kenya have contributed to reduction in criminalities and positive engagement of youths in Kenya. However, there has been a great deal of controversy and protracted debates amongst researchers to produce a universally accepted definition of what business unit can rightly be regarded as a small-scale industry. Considering the fact that the word "small" is ambiguous, hence, there is no yardstick for classifying business unit as a small scale. Therefore, small firms may be regard- 
ed as small-scale enterprises in relation to the level of economic development of a particular country (Ogunwole, 1997; Ebenezer, Paula, \& Allo, 2016; Matthew, Osabohien, Fagbeminiyi, \& Fasina, 2018b).

Statistics have shown that about $95 \%$ of the businesses in Nigeria are technically considered as micro, small and medium scale enterprises (SMEDAN, 2016). Micro and small-scale enterprises cover a wide range of industrial units and in any developing country, including Nigeria, they occupy an important position in the industrial sector, providing the supportive drive to enhanced the level of employment, development and contribute to national economy (Osabohien, Awolola, Matthew, Itua, \& Elomien, 2020). Micro and small-scale enterprises (MSEs) play a very important role in expanding and diversifying industrial production alongside their contribution to such basic goals as eradicating poverty, improving income distribution, meeting the basic needs of most developing countries and, most importantly, the job creation (Akinsanya, 1998).

Furthermore, extant literature widely acknowledges the usefulness of MSEs, especially in their role in job creation, particularly in developing countries such as Nigeria. It is estimated that $80 \%$ of the Nigerian workforce is engaged gainfully by micro and small-scale enterprises and studies have shown that these enterprises create more jobs than big businesses (Ojo, 2004). Job creation is therefore a dynamic concept referring to the ability of a system or an establishment to offer more employment opportunities to people in search of work (Mensah, 1997). Small businesses serve as a foundation for providing potential entrepreneurs (employers) who are always willing to explore new ideas at the slightest opportunity (Ogunwole, 1997; Babajide, Lawal, \& Somoye, 2015; Afolayan, Okodua, Matthew, \& Osabohien, 2019). Similarly, Afolabi, Kareem, Okubanjo, Ogunbanjo, and Aninkan (2017) suggest entrepreneurship education for young and willing new entrants to the MSEs' practice, with the intention to project a continual spread of MSE practice that can, in turn, provide a flow of job creation for applicants in the various industrial sectors. Moreover, sectoral operations are believed to be labour intensive, especially in a developing economy such as Nigeria, where capital investment on operational equipment tends to be at its minimal levels due to challenge relating to funding. Thus, it is more likely that MSEs stand a chance to keep creating jobs than larger organisations that are more likely to use innovation and new technologies to achieve efficiencies and economies of scale, thus, shedding labour (Mensah, 1997; Beaver, 2002).

In view of the above, this study explores how micro and small-scale enterprises have been able to create jobs for the applicants in Ado-Odo/Ota Local Government, Ogun State, Nigeria. The study, therefore, pays specific attention to the critical issues and partners' involvement with MSEs' operations in relation to the subject of job creation as well as the reverse effects of such efforts on MSEs' operations and the wider economy in the focus of this research. The study consists of six sections: section one is followed by this introductory section, which presents some insights from empirical literature. Section two presents the study's methodology; section three presents the results, section four discusses the empirical analysis of the study's results and findings; the last section concludes the study by recommending policies that will help improve micro and small enterprises' (MSEs) performance to create jobs for large number of unemployed people in Nigeria.

\section{LITERATURE REVIEW AND THEORETICAL FRAMEWORK}

It seems that micro and small-scale enterprises are easier to recognize in practice than to define (Ojo, 2004). However, in order to avoid rigidity and arbitrariness in identifying and properly categorizing the enterprises as small scale, a comprehensive character-based definition, which will embody the most significant attributes of MSEs, is essential (Ogunwole, 1997). In this regard, highlighting the common characteristics of small and medium-scale enterprises is necessary to enhance understanding of the concept of their operations. The Inquiry Committee on Small Businesses (Bolton, 1971) adopted several definitions of a small enterprise from two perspectives: economic terms and statistical terms. Under the economic definition of 
small enterprises (the broader category of micro, small and medium-sized enterprises), an enterprise can be considered small if:

1) it has a relatively small market share;

2) it is managed in a personalized manner by its owners or shareholders and not through a formalized management structure; and

3) it is independent in the sense that it is not part of a larger undertaking and that the owner/ manager should be free of external control and interference in making his or her main decision.

The Committee also employed statistical definitions useful in different sectors of the economy, defining micro and small businesses in terms of the number of persons that make up small firms in different sectors, for example, manufacturing, retailing, and so on (that is, the degree of smallness varied between sectors).The statistical definition would enable the international comparisons.

Some criteria have been applied by different institutions in defining micro and small-scale enterprises (Ogunwole, 1997). Micro and small-scale enterprises are establishments characterized by low level of investment, low level of turnover, low capital base, relatively simple production technology, relative inaccessibility to sources of institutional (long-term) financing (Akinsanya, 1998; Ojo, 2003; Matthew, Osabohien, Fagbeminiyi, \& Fasina, 2018; Afolayan, Okodua, Oaikhenan, \& Matthew, 2020). A worstcase scenario for MSEs' financing is confirmed in the findings of Akingunola, Olowofela, and Yunusa (2018), noting that there is a negative relationship between intermediary financial services such as micro finance banks and MSEs in Ogun state, Nigeria. These findings point to the confirmation of poor financial platforms on which MSEs operate that tend to pose a significant challenge to their prospect for growth and contributions towards national economic development. These suggestions tend to raise the question, what become the benefits of these MSEs from generating employment via their operations, if the public sector and other respective agencies are speculated to be negligent in providing sufficient support for their sustenance, especially in terms of financial support.
Whilst recognizing the access to institutional finance as a persistent pandemic issue for the development of SMEs in Nigeria, several schemes have been put in place by the Nigerian government in the past, including the Small Scale Industries Credit Scheme, NBCI (1973), NERFUND (1986), World Bank Assisted SME I (1985), World Bank Assisted SME II (1992), to provide special credit lines for small businesses, but these schemes have had very limited impact. In response to the incentives of the Federal Government of Nigeria, financial institutions have recently come up with a new initiative to reserve ten percent of their profit before tax for financing of micro, small and medium-sized enterprises in the form of participation in credit and equity. The government is also establishing several facilities for micro, small and medium-sized enterprises to improve access to institutional credit, which will provide affordable medium to long-term loans. These include creation of the Development Fund for Small and Medium Enterprises (SMEDFUND), Credit Guarantee Scheme, Nigerian Project Development Facility (NPDF), merging of Development Finance Institutions (DFIs), promotion of SME clusters and networks, improve incentives to invest in SMEs, infrastructural facilities, and even marketing of SME products.

Nevertheless, MSEs practitioners tend to stay resilient to the pursuit of their set operational objectives, and maintain their relevance in addressing the national economic challenges, such as addressing the unemployment. And, in most cases, these MSEs practitioners leverage on positive factors such as ease of establishment and focus of the entrepreneurs, amongst others, in driving their objectives, irrespective of the critical challenges to their operations (Osotimehin, Jegede, Akinlabi, \& Olajide, 2012). Corroborating this, Babajide (2012) affirms that the MSE sector provides a driving force to consistent job creation, poverty reduction, wealth creation, income distribution, and reduction in income disparities. He notes that frequently government interventions efforts fail to yield the needed transformation due to poor coordination and monitoring and policy inconsistencies, especially in Nigeria, where this research is based.

Furthermore, concerning the characteristics of MSEs, it is observed that since the publication of the Bolton 
Report, several comments have been made with respect to the shortcoming of the definition given by this committee. For instance, Stanworth and Gray (1991), pointed out that statistical analysis is severely hampered (that is, its progress is complicated) by the use of various definitions. Burns and Dewhurst (2016) opined that any definition that uses a financial indicator invariably requires periodic adjustment in order to take account of inflation. Furthermore, Storey (1994) stated two challenges he had when accepting the Bolton approach to defining small-scale enterprises. First, he notes the incompatibility of a definition that highlights the personalized nature of management while using statistical bands related to several employees simultaneously. He argued that there is sufficient research showing that firms employing up to 200 people would inevitably require that business decisions be taken by individuals who are not owners. The second argument of Storey challenges the influence which the notion of perfect competition (where small enterprises are price takers) has on the deliberations of the Bolton Committee, he argues that many small enterprises operate in niche markets (that is, where a limited and clearly defined product range is sold to a specific group of customers), where reduced prices offered as an incentive to purchase another product or service may be charged and higher business growth and performance may be shown. According to Storey (1994), there is still no single, uniformly acceptable definition of a small enterprises after more than 30 years of the publication of the Bolton Report. What emerges from a comprehensive review of small business literature is a range of definitions based on their values for specific projects justified by their users (Beaver, 2002).

According to the Third Nigerian National Development Plan (1975-1980), manufacturing industries that employ less than ten people or whose investment in machinery and equipment does not exceed NGN 600,000 are referred to as micro, small and medium-scale enterprises. In the same vein, Alana (1979) defined small business as a business in which a single (industry) person usually the proprietor dominates or take control of its activities. Small-scale enterprise, as defined by the small-scale industry development program of the Center for Management Development, is any business with twenty (20) full-time workers and capital investment not more than NGN500,000 in machinery and equipment. Under the 1996 CBN
Monetary and Credit Policy Guidelines, micro, small and medium-sized enterprises are defined as a company with fixed assets, excluding land, but not exceeding NGN 10,000,000, including working capital.

Alana (1979) gave a cost analysis of what constitutes small and medium-sized enterprises in his paper presented at the 5th Annual General Meeting of the Manufacturers Association of Nigeria (MAN). According to Obitayo (1991), contended that small and medium-scale enterprises are those with fixed asset and cost of investment project (land excluded) of up to NGN 2,000,000, while those with project cost not less than NGN 2,000,000 and not exceeding NGN 10,000,000 will be taken as medium scale. From Griffin and Ebert's (1996) point of view, a micro, small and medium-sized enterprise is an independently owned and managed enterprise and does not dominate its relevant interest market segment. In Ubom's (2003), opinion small-scale enterprise in Nigeria is defined as one that employs from 11 to100 workers, while medium-scale enterprise is one that employs from 101 to 300 workers. The introduction of the Structural Adjustment Program, however, creates a new concept for small and medium scale enterprises and the new concept recognizes small enterprises as those whose total fixed asset cost (excluding cost of land) is not more than NGN 10,000,000.

Micro and small-scale enterprises, in particular, in developing economies, play an important role in job creation. They serve as sources of employment to the army of unemployed people in Nigeria, particularly presently, that there is a high level of unemployment. An estimated $80 \%$ of the Nigerian workforce is employed by micro, small, and medium-sized enterprises. This is often so because this sector's operations are predominantly labour-intensive. Studies have shown that small and medium-sized enterprises create more jobs than large companies (Stokes, 2000). While extant literature widely acknowledges the positive effects of MSEs' operations on the economy, such as reduction of crime rates in the country (Babajide, 2012). Studies have highlighted the challenges of productivity in the engagement of labour, especially among MSEs in sub-Saharan Africa. They noted the critical reality in MSEs employment drive in terms of how effective such generated jobs are, first, to the employing MSEs, 
the engaged labour and, of course, the industry. This point tends to suggest the overriding for innovative approach that duly considers all the affected parties in the process of MSEs operations and their contributions towards addressing the unemployment in the Nigerian economy.

An attempt has been made to embark on a critical research process to achieve the objective of learning about the subject of MNEs' operations and their contributions to addressing the challenge of unemployment in Ado-Odo/Ota Local Government Area, Ogun State, Nigeria. The jobs theory of growth is adopted in this research. The jobs theory assumes that 'demand creates supply'. This implies that if consumers have incomes, business enterprises will supply products to them because they will have money to buy the products produced by these enterprises. The end result of this theory assumes that when more jobs are created, then the economy would experience growth.

The choice of these theories stems from the fact that micro and small-scale enterprises help to generate employment, which, in turn, contributes to aggregate output and, hence, boosts economic growth. When these MSEs produce goods, they tend to enjoy economies of scale. However, the shortcoming of these theories is that SMEs do not employ many employees as expected because of their small size and they do not produce on a large scale, thus, they do not enjoy reduced cost of production as to make them experienced economies of scale. This is one gap in the literature that other subsequent studies should fill in future.

These adopted theories tend to enhance the needed focus of this research because the MSEs' operations are embedded on meaningful engagement with the business environments (Ufua, 2019). This factor creates the platform for critical research that embraces further learning on the subject of MSEs' operations and their effects on addressing the challenge of unemployment, especially in focus of this research. This also aligns well with current trends of research on addressing wicked economic and social problems, such as unemployment challenge, analysed in this research .It is to adopt a combination of diverse theoretical and methodical approach that can duly identify with stakeholders who are either involved or affected by the identi- fied problem situation (Gregory, Atkins, Midgley, \& Hodgson, 2019; Giordano, Pluchinotta, Pagano, Scrieciu, \& Nanu, 2020).

\section{METHODOLOGY}

\subsection{Research design}

In this study, the simple random sampling technique is adopted in selecting the sample for the study. The respondents of the administered questionnaires in the sample areas were randomly selected. The study sample is selected from the study population that includes micro and small-scale enterprises and employees in Ado-Odo/Ota Local Government Area in Ogun State. The study's targeted sample size is one thousand $(1,000)$ in all, consisting of 700 enterprises and 300 micro and small enterprises' employees in the study local government area. The study used the primary data through the administration of one thousand $(1,000)$ copies of questionnaires to respondents. Copies of the questionnaires were piloted in a similar but different location from focus of this research. Items on the first questionnaire draft were duly reviewed by contemporary researchers and later adopted in line with the basic objective on this research (Kets De Vries, Vrignaud, Agrawal, \& FlorentTreacy, 2010). This study aims to serve as a means of making the policy makers aware that MSEs' operations contribute towards addressing the problem of unemployment in Nigeria, specifically, in areas like Ado-Odo, Iyana Iyesi, Atan Ota, Ijoko Ota, Iju, Itele, Onibukun, Chelsea, Igbesa, Oju Oore, Ajegunle, Lusada, Sango, and Korogboji. The research design has been carefully prepared to ensure minimum biasness in the collection of data needed to reduce error in the analysis and interpretation of the information gathered.

Ado-Odo/Ota Local Government Area is one of the 19 local government areas of Ogun State, Nigeria. Ado-Odo/Ota Local Government Area came into being on May 19, 1989. Ado-Odo/Ota adjoins metropolitan Lagos as it is very close to the city. The Local Government Area is the second largest in Ogun State and is headquartered at the north of the area at $6^{\circ} 41^{\prime} 00^{\prime \prime} \mathrm{N}^{\circ} 41^{\prime} 00^{\prime \prime} \mathrm{E}$. It is an industrial area that generates huge revenue (from taxes imposed on enterprises) to the Ogun State Government because of the presence of industries and small enterprises. The 
inhabitants of the Local Government Area are made up of mostly the Awori people, a part of the Yorubas (Olukanni \& Mnenga, 2015).

\subsection{Model specification}

This study adopted the model in the work of Matthew et al. (2018b). The model in this study is formulated as follows:

$$
E L M S E=f(X, Y),
$$

where ELMSE - employment level in micro and small enterprises; $X$ is the vector of characteristics of the enterprises; $Y$ is the vector of characteristics of the entrepreneurs (employees).

In equation (1), under the characteristics of the enterprises denoted by $X$, the independent variables include age of the business $(A B)$, organisation's average weekly turnover $(A W T)$, number of employees at the start of the business (ESB), and even the present capital of the enterprises $(P C)$. Under the characteristics of the entrepreneurs denoted as $Y$, the educational qualification of the employers $(E A)$ comes in:

$$
X=A B, A W T, E S B \text {, and } P C ; Y=E A .
$$

Bringing together the variables under both vectors $X$ and $Y$ and substituting them into equation (1), one has the equation in implicit form as:

$$
E L M S E=f(A B, E A, A W T, E S B, P C) .
$$

From equation (2), one makes the equation explicit as we have in equation (3):

$$
\begin{aligned}
& E L M S E=\alpha_{0}+\alpha_{1} A B+\alpha_{2} E A+ \\
& +\alpha_{3} A W T+\alpha_{4} E S B+\alpha_{5} P C+\mu,
\end{aligned}
$$

where ELMSE is current employment level (captured by the number of employees employed presently), $A B$ is age of business, $E A$ is educational attainment of employers, $A W T$ is organisation's average weekly turnover now, ESB is the number of employees at the start of the business, $P C$ is the present capital of the business, $\mu=$ stochastic term. In terms of the 'a priori' expectations, the coefficients $\alpha_{1} \ldots \alpha_{5}$ are positive, that is, all the independent variables are positively related with the dependent variable.

\section{RESULTS}

This section presents the data obtained in tables and the results discussed. Table 1 presents the socio-demographic characteristics of the respondents. The information presented in this section is intended to facilitate the interpretation of the main variables relating to micro and small-scale enterprises' socio-demographic characteristics.

\begin{tabular}{|c|c|}
\hline \multicolumn{2}{|c|}{ Age of respondents } \\
\hline Less than 20 years & 80 \\
\hline $21-30$ years & 150 \\
\hline $31-40$ years & 500 \\
\hline $41-50$ years & 270 \\
\hline Total & 1,000 \\
\hline \multicolumn{2}{|c|}{ Marital status of respondents } \\
\hline Single & 250 \\
\hline Married & 350 \\
\hline Divorced & 150 \\
\hline Widowed & 250 \\
\hline Total & 1,000 \\
\hline
\end{tabular}

Table 1. Socio-demographic characteristics

\begin{tabular}{|c|c|}
\hline Total & 1,000 \\
\hline \multicolumn{2}{|c|}{ Religion of respondents } \\
\hline Christianity & 480 \\
\hline Islam & 420 \\
\hline Others & 100 \\
\hline Total & 1,000 \\
\hline \multicolumn{2}{|c|}{ Nationality of respondents } \\
\hline Nigerian & 850 \\
\hline Non-Nigerian & 150 \\
\hline Total & 1,000 \\
\hline \multicolumn{2}{|c|}{ Types of enterprises } \\
\hline Bakery & 200 \\
\hline Pure water making & 220 \\
\hline Soap making & 110 \\
\hline Poultry farms & 110 \\
\hline Printing press & 180 \\
\hline Tailoring & 180 \\
\hline Total & 1,000 \\
\hline
\end{tabular}
of the respondents

Source: Authors' computation from survey data (2019)

\begin{tabular}{lcc}
\hline \multicolumn{1}{c}{ Variables } & Frequency \\
\hline \multicolumn{1}{c}{ Respondents' educational qualification } \\
\hline Primary & 330 \\
\hline Secondary & 380 \\
\hline Tertiary & 280 \\
\hline Others (M.Sc) & 10 \\
\hline Total & & 1,000 \\
\hline \multicolumn{3}{c}{ Gender of respondents } \\
\hline Male & \\
\hline Female & & 550 \\
\hline Total & & 450 \\
\hline
\end{tabular}


The results of the profitability characteristics of enterprises surveyed are presented in Table 2.

Table 2. Profitability characteristics of enterprises surveyed

\begin{tabular}{|c|c|c|}
\hline Variables & Frequency & Percentage \\
\hline \multicolumn{3}{|c|}{ Years of enterprise's establishment } \\
\hline Less than a year & 60 & 6.0 \\
\hline $1-4$ years & 200 & 20.0 \\
\hline $5-9$ years & 350 & 35.0 \\
\hline 10 years and above & 390 & 39.0 \\
\hline Total & 1,000 & 100.0 \\
\hline \multicolumn{3}{|c|}{ Enterprise's initial capital } \\
\hline Less than NGN 100,000 & 350 & 35.0 \\
\hline NGN 100,001-NGN 200,000 & 280 & 28.0 \\
\hline NGN 200,001-NGN 300,000 & 200 & 20.0 \\
\hline NGN 300,001 and above & 170 & 17.0 \\
\hline Total & 1,000 & 100.0 \\
\hline \multicolumn{3}{|c|}{ Enterprise's present capital } \\
\hline Less than NGN 200,000 & 370 & 37.0 \\
\hline NGN 200,001-NGN 300,000 & 230 & 23.0 \\
\hline NGN 300,001-NGN 400,000 & 210 & 21.0 \\
\hline NGN 400,001 and above & 190 & 19.0 \\
\hline Total & 1,000 & 100.0 \\
\hline
\end{tabular}

\begin{tabular}{|c|c|c|}
\hline \multicolumn{3}{|c|}{ Average weekly turnover at business start } \\
\hline Less than NGN 24,999 & 300 & 30.0 \\
\hline NGN 25,000-NGN 49,999 & 330 & 33.0 \\
\hline NGN 50,000-NGN 99,999 & 280 & 28.0 \\
\hline NGN 100,000 and above & 90 & 9.0 \\
\hline Total & 1,000 & 100.0 \\
\hline \multicolumn{3}{|c|}{ Average weekly turnover now } \\
\hline Less than NGN 49,999 & 290 & 29.0 \\
\hline NGN 50,000-NGN 99,999 & 310 & 31.0 \\
\hline NGN 100,000-NGN 199,999 & 290 & 29.0 \\
\hline NGN 200,000 and above & 110 & 11.0 \\
\hline Total & 1,000 & 100.0 \\
\hline \multicolumn{3}{|c|}{ Average profit margin for the first month of business } \\
\hline \multicolumn{3}{|l|}{ Less than NGN 49,999 } \\
\hline \multicolumn{3}{|l|}{ NGN 50,000-NGN 99,999 } \\
\hline \multicolumn{3}{|l|}{ NGN 100,000-NGN 149,999 } \\
\hline \multicolumn{3}{|l|}{ NGN 150,000 and above } \\
\hline Total & 1,000 & 100.0 \\
\hline \multicolumn{3}{|c|}{ Current average profit margin } \\
\hline \multicolumn{3}{|l|}{ Less than NGN 49,999 } \\
\hline \multicolumn{3}{|l|}{ NGN 50,000-NGN 99,999 } \\
\hline \multicolumn{3}{|l|}{ NGN 100,000-NGN 149,999 } \\
\hline \multicolumn{3}{|l|}{ NGN 150,000 and above } \\
\hline Total & 1,000 & 100.0 \\
\hline
\end{tabular}

The results in Table 3 showed the employment generated by the sampled enterprises.
Table 3. Job creation in the enterprises surveyed

Source: Authors' computation from survey data (2019).

\begin{tabular}{|c|c|c|}
\hline Variables & Frequency & Percentage \\
\hline \multicolumn{3}{|c|}{ Number of employees at business start } \\
\hline None & 200 & 20.0 \\
\hline $1-2$ & 250 & 25.0 \\
\hline $3-5$ & 400 & 40.0 \\
\hline 6 and above & 150 & 15.0 \\
\hline Total & 1,000 & 100.0 \\
\hline \multicolumn{3}{|c|}{ Number of employees presently } \\
\hline $1-5$ & 180 & 18.0 \\
\hline $6-10$ & 250 & 25.0 \\
\hline $11-15$ & 350 & 35.0 \\
\hline 16 and above & 220 & 22.0 \\
\hline Total & 1,000 & 100.0 \\
\hline \multicolumn{3}{|c|}{ Number of employees expected in the next three years } \\
\hline $1-5$ & 220 & 22.0 \\
\hline $6-10$ & 170 & 17.0 \\
\hline $11-15$ & 320 & 32.0 \\
\hline 16 and above & 290 & 29.0 \\
\hline Total & 1,000 & 100.0 \\
\hline
\end{tabular}

The results in Table 4 showed the Ordinary Least Square (OLS) regression result of the model specified.

Table 4. OLS regression result

\begin{tabular}{|c|c|c|c|}
\hline & Coefficient & T-statistics & Sig. \\
\hline (Constant) & .355 & .334 & .739 \\
\hline$A B$ & $.312^{* * *}$ & 3.084 & .003 \\
\hline EA & $607^{* * *}$ & 7.114 & .000 \\
\hline AWT & $.098^{* * *}$ & 3.081 & .003 \\
\hline ESB & -.052 & -.670 & .052 \\
\hline PC & -.065 & -.445 & .065 \\
\hline $\mathrm{R}^{2}$ & & 0.628 & \\
\hline $\operatorname{Adj} \cdot R^{2}$ & & 0.581 & \\
\hline $\mathrm{F}$ & & 20.182 & \\
\hline Prob. & & 0.000 & \\
\hline
\end{tabular}

Note: ${ }^{* * *}$ significant at $1 \%$ level of significance.

\section{DISCUSSION OF RESULTS}

The results in Table 1 revealed that education of respondents presents the following information: primary education respondents were $33 \%$; most respondents have certificates of junior and secondary school (38\%). Besides, respondents with post-secondary education that includes degrees in polytechnics and universities were $28 \%$, while $9 \%$ of respondents had advanced education levels. Gender findings 
showed that a majority of the respondents ( 55 percent) were males, while $45 \%$ were female respondents. The respondents' age range was between 18 and 50 years. Group age refers to the interval of ten years. Findings also indicated that $8 \%$ were below 20 years, the highest ratio was between $31-40$ years with 50\%; those in age categories $21-30$ years were $15 \%$; similarly, 27\% were $41-50$ years of age group. This finding corroborates the report of the Population Division of the United Nations Department of Economic and Social Affairs (2016), where it has been argued that adults are the majority of the Nigerian population.

The distribution of marital status of respondents showed that $25 \%$ were single, $35 \%$ married, $15 \%$ divorced, and $25 \%$ widowed. It is evident from statistics show that the respondents' highest proportions were married. The religious distribution showed that three major religions in Nigeria were practiced by the respondents. The study found that the larger percentage of respondents practiced Christianity (58\%), followed by Islam (42\%), and only $10 \%$ practiced some forms of African Traditional Religion (ATR). Nationality of the respondents had a wide margin. The distribution of respondents' nationality showed that $85 \%$ were Nigerians, while $15 \%$ were non-Nigerians. Distribution of respondents by types of enterprises indicated that $20 \%$ were engaged in baking, $22 \%$ were engaged in sachet water making, $11 \%$ were engaged in soap making, $11 \%$ were engaged in poultry farms, $18 \%$ were engaged in printing press, and $18 \%$ engaged in tailoring. The result shows that the respondents' types of engagement had a close margin.

The results in Table 2 revealed that the years of distribution of enterprise's establishment showed that less than a year ago 6 percent of respondents set up their enterprises; $20 \%$ of the respondents established their enterprises less than four years ago. Furthermore, $35 \%$ of the respondents established their enterprises from 5 to 9 years ago. The highest respondents' enterprise's establishment, above 10 years, was $39 \%$. The distribution of respondents' enterprise initial capital indicated that $35 \%$ of the respondents had less than NGN100,000, 28\% of the respondents accounted less than NGN 200,000, similarly, $20 \%$ of the respondents accounted less than NGN 300,000 while $17 \%$ accounted for more than NGN 300,000. The distribution of respondents' enterprise present capital indicated that $37 \%$ of the respondents had less than NGN
$200,000,23 \%$ of the respondents accounted less than NGN 300,000. Similarly, 21\% of the respondents accounted less than NGN 400,000, while 19\% accounted for more than NGN 400,000. Findings on respondents' average weekly turnover at business start indicated that $30 \%$ of the respondents had less than NGN 25,000,33\% of the respondents accounted less than NGN $50,000,28 \%$ of the respondents accounted less than NGN 100,000 , while $9 \%$ of the respondents accounted for more than NFN 100,000. The distribution of respondents' average weekly turnover showed that $29 \%$ of the respondents had less than NGN $50,000,60 \%$ of the respondents accounted for less than NGN 200,000. Furthermore, 11\% of the respondents accounted above NGN 200,000.

The result in Table 3 showed that $20 \%$ had no employees at the start of business, $25 \%$ of the enterprises employed between 3 and 5 employees at the start of business, $40 \%$ of the enterprises had between 3 and 5 employees, while $15 \%$ employed more than $6 \mathrm{em}$ ployees. Concerning the number of employees, the enterprises presently have, $18 \%$ of the enterprises have 1 to 5 employees, 25\% of the enterprises had 6 to 10 employees, $35 \%$ of the enterprises have 11 to 15 employees, while $22 \%$ of the enterprises have more than 16 employees. Concerning the number of employees expected to be employed in the next 5 years, the results showed that $22 \%, 17 \%, 32 \%$, and $29 \%$ of the enterprises hope to have 1-5, 6-10, 11-15, and more than 16 employees, respectively. In summary, these results show that there has been an improvement in the jobs created by these MSEs.

The results in Table 4 were obtained from the model that was specified in order to verify empirically if the MSEs have contributed to job creation, all the explanatory variables have a positive relationship with the dependent variable, which supports what theory says. This implies that the explanatory variables help to increase job creation in the MSEs. However, the only variables that have significant impact on job creation are the age of business, educational attainment, and the organization's average weekly turnover; they are all significant at $1 \%$ level of significance. The result also revealed that the $R^{2}$ is 0.628 , which implies that all the explanatory variables explain $62.8 \%$ of the job creation by the micro and small-scale enterprises, while the remaining $38.2 \%$ are explained by other factors not captured in this study but represented by the error term. 


\section{CONCLUSION AND RECOMMENDATIONS}

This study analysed how micro and small enterprises (MSEs) had contributed to job creation in Ado-Odo/Ota Local Government Area in Ogun State, Nigeria. From the data collected and the analysis, the study could find out empirically that MSEs affect job creation greatly, and the extent to which they will have greater impact on employment depends on the encouragement they receive from the government. These encouragements are in terms of granting the investors soft loans, giving them tax rebates, amongst other things. However, it is important that more policies should be added to those on ground and implemented effectively in order to improve, encourage, and promote the activities of these micro and small enterprises.

Based on the results of this study, the following recommendations are made: first, the government should provide a reliable platform for easier access to MSE credit facilities; they should create micro, small, and medium enterprises development banks through which small enterprises can approach for financial credit funding at affordable and subsidized collateral security demands. These banks should be established with the sole aim of giving out soft loans with little interest rates to small enterprises. Second, the micro and small enterprises (MSEs) operators should be given tax and tariff concessions (for instance, tax rebate or holiday).It would help them to grow as the amount that ought to be paid would be ploughed back into the business. Thus, if their enterprises grow, they will be able to employ more people in the long run. Besides, it is advised for these creditors' agencies (for example, banks) to pay attention to the trend of economic support activities of MSEs such as their performance records in terms of job creation, as part of the criteria for assessing such funding. Such could further enhance the practicing MSEs' interest in contributing to the host economy. Lastly, the government should establish micro and small-scale development agencies, in remote and developing locations such as Ado-Odo/Ota Local Government Area in Ogun State, Nigeria, where this research was based. This is essential as it would make the access to the needed MSEs' support easier and also create more awareness through effective interactions with these operational partners who can re-assure them of the positive effects of their operations on the host economy that would be charged with the specific responsibility of ensuring the proper running of MSEs, controlling their operations, and making sure the enterprises do the right things at the right time and the right place. The MSE development agencies would ensure the promotion of the activities of micro and small-scale enterprises.

\section{AUTHOR CONTRIBUTIONS}

Data curation: Romanus Osabohien.

Formal analysis: Oluwatoyin A. Matthew, Romanus Osabohien.

Investigation: Daniel E. Ufua, Tomike Olawande, Oluwatosin D. Edafe.

Methodology: Oluwatoyin A. Matthew, Daniel E. Ufua, Romanus Osabohien, Oluwatosin D. Edafe.

Supervision: Oluwatoyin A. Matthew.

Writing - original draft: Oluwatoyin A. Matthew, Daniel E. Ufua, Tomike Olawande, Oluwatosin D.

Edafe.

Writing - review \& editing: Daniel E. Ufua, Romanus Osabohien, Tomike Olawande, Oluwatosin D. Edafe.

\section{ACKNOWLEDGMENT}

The authors appreciate the Management of Covenant University for funding the publishing of this manuscript in this journal. 


\section{REFERENCES}

1. Afolabi, M. O., Kareem, F. A., Okubanjo, I. O., Ogunbanjo, O. A., \& Aninkan, O. O. (2017). Effect of Entrepreneurship Education on Self-Employment Initiatives among Nigerian Science \& Technology Students. Journal of Education and Practice, 8(15), 44-51. Retrieved from https://eric. ed.gov/?id=EJ1143880

2. Afolayan, O. T., Okodua, H., Matthew, O., \& Osabohien, R. (2019). Reducing unemployment malaise in Nigeria: The role of electricity consumption and human capital. International Journal of Energy Economics and Policy, 9(4), 63-73. https://doi. org/10.32479/ijeep.7590

3. Afolayan, O.T., Okodua, H., Oaikhenan, H., \& Matthew, O. (2020). Carbon emissions, human capital investment and economic development in Nigeria. International Journal of Energy Economics and Policy, 10(2), 427437. https://doi.org/10.32479/ ijeep. 8476

4. Akingunola, R. O., Olowofela, E. O., \& Yunusa, L. (2018). Impact of microfinance banks on micro and small enterprises in Ogun State, Nigeria. Binus Business Review, 9(2), 163-169. https://doi. org/10.21512/bbr.v9i2.4253

5. Akinsanya, O. R. (1998). Small scale enterprises and economic development in Nigeria (Unpublished Thesis). Lagos State University, Nigeria.

6. Alana, D. (1979). Small business in Eastern Nigeria. Lagos: African Publishers Limited.

7. Babajide, A. A., Lawal, A. I., \& Somoye, R. O. (2015). Monetary policy dynamics and stock market movements: Empirical evidence from Nigeria. Journal of Applied Economic Science, 10(8), 11791188. Retrieved from http:// eprints.covenantuniversity.edu. ng/6454/1/Babajide\%205.pdf

8. Babajide, A. A. (2012). Effects of microfinance on micro and small enterprises (MSEs) growth in Nigeria. Asian Economic and
Financial Review, 2(3), 463-477.

Retrieved from https://www. semanticscholar.org/paper/ Effects-of-Microfinance-on-Micro-and-Small-(MSEs)-Babajide/ c0aab8aebbfbece95c6b8c124e24c$720 f 364 a a 76$

9. Beaver, G. (2002). Small business, entrepreneurship and enterprise development. Edinburgh Gate: Pearsons Education Limited.

10. Beecroft, I., Osabuohien, E. S., Efobi, U. R., Olurinola, I., \& Osabohien, R. A. (2020). Manufacturing Export and ICT Infrastructure in West Africa: Investigating the Roles of Economic and Political Institutions. Institutions and Economies, 12(1), 1-36. https://ijie. um.edu.my/article/view/22021

11. Bolton, J. E. (1971). Small Firms: report of the Committee of Inquiry on Small Firms. London: HMSO. Retrieved from https://ipmall.law. unh.edu/sites/default/files/BAYHDOLE/3_DIV_SCAN/2791_001_ OCR_DIV.pdf

12. Burns, P., \& Dewhurst, J. (Eds.). (2016). Small business and entrepreneurship. London: Macmillan International Higher Education.

13. Central Bank of Nigeria. (1988). Annual Report. Lagos: CBN Publication.

14. Ebenezer, A. J., Paula, A. M., \& Allo, T. (2016). Risk and investment decision making in the technological age: A dialysis of cyber fraud complication in Nigeria. International Journal of Cyber Criminology, 10(1), 62-78. https://doi.org/10.5281/zenodo. 58522

15. Federal Ministry of Economic Development and Reconstruction (1975). Third National Development Plan (1975-1980) (353p.). Lagos: Central Planning Office, Federal Ministry of Economic Development.

16. Giordano, R., Pluchinotta, I., Pagano, A., Scrieciu, A., \& Nanu, F. (2020). Enhancing nature-based solutions acceptance through stakeholders' engagement in co-benefits identification and trade-offs analysis. Science of the Total Environment, 713, 136552. https://doi.org/10.1016/j.scitotenv.2020.136552

17. Gregory, A. J., Atkins, J. P., Midgley, G., \& Hodgson, A. M. (2019). Stakeholder identification and engagement in problem structuring interventions. European Journal of Operational Research, 283(1), 321-340. https:// doi.org/10.1016/j.ejor.2019.10.044

18. Griffin, R.W., \& Ebert, R.J. (1996). Business. New Jersey: Prentice Hall Inc.

19. Igharo, E. A., Osabohien, R., Onyemariechi, G., \& Ibidapo, D. T. (2020). Monetary policy transmission mechanism, innovative banking system and economic growth dynamics in Nigeria. International Journal of Business Innovation and Research, 21(1), 1-22. https://doi. org/10.1504/IJBIR.2020.104032

20. Kets De Vries, M. F., Vrignaud, P., Agrawal, A., \& Florent-Treacy, E. (2010). Development and application of the leadership archetype questionnaire. The International Journal of Human Resource Management, 21(15), 2848-2863. https://doi.org/10.1080 /09585192.2010.528668

21. Matthew, O., Ede, C. U., Osabohien, R., Ejemeyovwi, J., Fasina, F. F., \&Akinpelumi, D. (2018a). Electricity consumption and human capital: Implications for economic growth in Nigeria. International Journal of Energy Economics and Policy, 8(6), 8-15. https://doi.org/10.32479/ ijeep.6758

22. Matthew, O., Osabohien, R., Fagbeminiyi, F., \& Fasina, A (2018b). Greenhouse gas emissions and health outcomes in Nigeria: Empirical insight from Auto-regressive Distribution Lag Technique. International Journal of Energy Economics and Policy, 8(3), 43-50. Retrieved from https://covenantuniversity.edu.ng/content/ download/60115/406789/file/Publ ished+version+Gas+Emissions+an $\mathrm{d}+$ Health+Outcome.pdf 
23. Mensah, S. N. (1997). Small scale industries and employment opportunities: Theoretic consideration in policy issues (in small scale industrial development in Nigeria). Jos: CDS.

24. Obitayo, K. M. (1991, July/ September). Government industrial policies in respect of small and medium enterprises in Nigeria. CBN Bullion, 15(3).

25. Ogunwole, B.O. (1997). The contribution of small-scale business to the development of the Nigerian economy: A case study of Lagos metropolis (Unpublished N.C.E Project). Adeniran Ogunsanya College of Education, OtoIjanikin, Nigeria.

26. Ojo, O. (2003). Fundamentals of Research Methods. Lagos: Standard Publication.

27. Ojo, T.A. (2004). Small and medium enterprises development and SMIEIS - Effective implementation strategies. Lagos: CIBN Press Limited. Retrieved from http://mtu.edu.ng/mtu/oer/ extra/JAT-OJO_SMEDevAndSMEIES.pdf

28. Olukanni, D. O., \& Mnenga, M. U. (2015). Municipal solid waste generation and characterization: A case study of Ota, Nigeria. International Journal of Environmental Science and Toxicology Research, 3(1), 1-8. Retrieved from http://www. internationalinventjournals.org/ journals/IJESTR
29. Osabohien, R., Osuagwu, E., Osabuohien, E., Ekhator-

Mobayode, U. E., Matthew, O., \& Gershon, O., (2020). Household access to agricultural credit and agricultural production in Nigeria: A propensity score matching model. South African Journal of Economic and Management Sciences, 22(1), 2688. Retrieved from https://sajems. org/index.php/sajems/article/ view/2688

30. Osabohien, R., Awolola, O. D., Matthew, O., Itua, S. Q., \& Elomien, S. (2020). Foreign direct investment inflow and employment in Nigeria. Investment Management and Financial Innovations, 17(1), 77-84. http://dx.doi.org/10.21511/ imfi.17(1).2020.07

31. Osotimehin, K. O., Jegede, C. A., Akinlabi, B. H., \& Olajide, O. T. (2012). An evaluation of the challenges and prospects of micro and small-scale enterprises development in Nigeria.

American International Journal of Contemporary Research, 2(4), 174-185. Retrieved from https:// www.semanticscholar.org

32. Shibia, A. G., \& Barako, D. G. (2017). Determinants of micro and small enterprises growth in Kenya. Journal of Small Business and Enterprise Development, 24(1),
105-118. https://doi.org/10.1108/ JSBED-07-2016-0118

33. Small and Medium scale Enterprises Development Agency of Nigeria (SMEDAN) (2016). Annual Publication.

34. Stanworth, J., \& Gray, C. (1991). Bolton 20years on: The small firms in the 1990s. London: Paul ChapmanPublishing.Retrieved from https://www.researchgate. net/publication/228314173 Bolton_20_Years_On_The_Small_ Firm_in_the_1990s

35. Stokes, D. (2000). Small business management: A case study approach (3rd ed.). Gosport: Ashford Colour Press. Retrieved from https://www.abebooks. fr/9780826453891/SmallBusiness-Management-CaseStudy-0826453899/plp

36. Storey, D. (1994). Understanding the small business sector. London: Routledge. https://doi. org/10.4324/9781315544335

37. Ubom, E. E. (2003). Entrepreneurship, small and medium enterprises (theory, practice and policies). Lagos: Sendina Limited.

38. Ufua, D. E. (2019). Exploring the effectiveness of boundary critique in an intervention: A case in the Niger Delta Region, Nigeria. Systemic Practice and Action Research, 1-15. https://doi. org/10.1007/s11213-019-09493-w 